\title{
MODEL SYSTEM DYNAMICS INFRASTRUKTUR BTS RAMAH LINGKUNGAN DAERAH RURAL UNTUK OPTIMALISASI PERHITUNGAN ARPU
}

\author{
Wahyu Sardjono \\ Information Systems Department, School of Information Systems, Binus University \\ Jl. K.H. Syahdan No. 9, Palmerah, Jakarta Barat 11480 \\ wahyu.s@binus.ac.id
}

\begin{abstract}
Green Base transceiver station (BTS) or known as remote BTS is a special BTS with IP technologybased that has a small capacity and takes low power consumption with standard features suitable for use in rural areas. BTS utilizes 100\% solar energy as a source of energy. The infrastructure Green BTS is composed of high-tech devices which is able to save energy, environmentally friendly, small and lightweight. The high rate service calls and SMS on green BTS is caused by the absence of competition telecom operators at a site. The solution to this problem needs to be done with system dynamics modeling approach with the aim to establish causality (cause and effect) between the variables. The standard target of model pattern which has been changed on system dynamics can be used to demonstrate the behavior of the model between the number of subscribers, the availability of network capacity and ARPU (average revenue per user) on the Green BTS site. On the changed standard target model, the actual revenue is placed as the actual event, the target revenue is as a target; the difference between the actual and target revenue is as gap, gap changes are as the pressure on the target and the corrective action taken against revenue as a corrective action. Based on simulation results, the standard model change targets can be developed by adding two negative loops (balancing loop) as an alternative solution towards the achievement of revenue targets that have been set.
\end{abstract}

Keywords: BTS Green, revenue, ARPU, system dynamics, changed standard model

\begin{abstract}
ABSTRAK
Base transceiver station (BTS) ramah lingkungan atau BTS remote adalah BTS khusus berbasis teknologi IP yang memiliki kapasitas kecil dan berkonsumsi daya rendah dengan fitur-fitur standar yang cocok digunakan di daerah rural. BTS ini memanfaatkan $100 \%$ energi matahari sebagai sumber energinya. Infrastruktur BTS Ramah Lingkungan tersusun atas perangkat-perangkat berteknologi canggih, hemat energi, ramah lingkungan, berukuran kecil dan berbobot ringan. Tingginya tarif layanan call dan SMS pada BTS Ramah Lingkungan disebabkan oleh belum adanya kompetitor operator telekomunikasi pada suatu lokasi. Pemecahan terhadap masalah yang ada perlu dilakukan dengan pendekatan model system dynamics dengan tujuan untuk membentuk hubungan kausalitas (sebab akibat) antar variabel-variabel. Pola model baku sasaran yang berubah (target has changed) pada System Dynamics dapat digunakan untuk menunjukkan perilaku model antara jumlah pelanggan, ketersediaan kapasitas jaringan dan ARPU (Average Revenue Per User) pada site BTS Ramah Lingkungan. Dalam model baku sasaran yang berubah, aktual revenue ditempatkan sebagai kejadian aktual, target revenue sebagai sasaran, selisih aktual dan target revenue sebagai gap, perubahan gap sebagai tekanan terhadap sasaran dan tindakan perbaikan yang dilakukan terhadap revenue sebagai tindakan koreksi. Berdasarkan hasil simulasi, model baku sasaran yang berubah dapat dikembangkan dengan menambah dua lup negatif (balancing loop) sebagai alternatif solusi menuju pencapaian target revenue yang telah ditetapkan.
\end{abstract}

Kata kunci: BTS Ramah Lingkungan, revenue, ARPU, system dynamics, model baku sasaran yang berubah 


\section{PENDAHULUAN}

Sistem telekomunikasi yang handal dengan menggunakan infrastruktur telekomunikasi yang tepat guna terus dikembangkan baik di daerah perkotaan (urban) maupun pedesaan (rural). Pembangunan infrastruktur telekomunikasi di daerah rural diharapkan dapat menjangkau hingga ke pelosok-pelosok daerah yang potensial. Operator-operator telekomunikasi di Indonesia seperti Telkomsel atau Indosat, telah memiliki program pembangunan infrastruktur telekomunikasi di daerahdaerah rural untuk memperlancar komunikasi daerah rural dengan dunia luar serta membantu pengembangan ekonomi daerah.

Pembangunan berkelanjutan (Sustainable development) bertujuan untuk meningkatkan kesejahteraan masyarakat, memenuhi kebutuhan dan aspirasi manusia (Aziz, et al., 2010). Pembangunan yang berkelanjutan pada hakekatnya ditujukan untuk mencari pemerataan pembangunan antar generasi pada masa kini maupun masa mendatang. Sementara menurut Fauzi (2004), konsep keberlanjutan paling tidak mengandung dua dimensi. Pertama adalah dimensi waktu karena keberlanjutan tidak lain menyangkut apa yang akan terjadi dimasa yang akan datang. Kedua adalah dimensi interaksi antara sistem ekonomi dan sistem sumber daya alam dan lingkungan (Falk, 2009)

Di lain pihak para ahli sepakat untuk sementara mengadopsi pengertian yang telah disepakati yang menyatakan bahwa "Pembangunan berkelanjutan adalah pembangunan yang memenuhi kebutuhan generasi saat ini tanpa mengurangi kemampuan generasi mendatang untuk memenuhi kebutuhan mereka” (Salim, 2006). Tiga aspek yang terdapat dalam pembangunan berkelanjutan yaitu aspek ekonomi, aspek lingkungan dan aspek sosial. Keberadaan infrastruktur BTS ramah lingkungan di daerah rural sangat erat kaitannya dengan konsep tersebut (Struzak, 2007)

Pada tahun 2010, melalui Program Indonesia Hijau, Indosat berhasil membangun 7 BTS ramah lingkungan, yaitu BTS khusus berbasis teknologi IP yang memiliki kapasitas kecil, konsumsi daya rendah dan fitur-fitur standar yang cocok digunakan di daerah rural yang memanfaatkan $100 \%$ energi matahari sebagai sumber energinya, pada 6 lokasi di Desa Mambi (Sulawesi).

Ditinjau dari sisi bisnis keberadaan Infrastruktur BTS ramah lingkungan, ada hal-hal yang perlu di pantau setelah site tersebut mulai dioperasikan, untuk harmonisasi keberlanjutan bisnis perlu dibuat suatu model keseimbangan dinamis yang dapat menjelaskan hubungan antara jumlah pelanggan, kapasitas jaringan, ARPU dan revenue. Model tersebut diharapkan dapat dipergunakan untuk memprediksi kondisi aktual di masa yang akan datang sekaligus menjadi acuan bagi operator telekomunikasi untuk mengambil tindakan korektif guna mengantisipasi kondisi di lapangan yang sifatnya dinamis, dan berubah terhadap waktu.

System dynamics adalah suatu metode pemodelan yang diperkenalkan oleh Jay Forrester pada tahun 1950-an dan dikembangkan di Massachusetts Institute of Technology Amerika. Sesuai dengan namanya, penggunaan metode ini erat berhubungan dengan pertanyaan-pertanyaan tentang tendensitendensi dinamik sistem-sistem yang kompleks, yaitu pola-pola tingkah laku yang dibangkitkan oleh sistem itu dengan bertambahnya waktu (Akkermans dan Dellaert, 2005).

System dynamics adalah sebuah pendekatan untuk memahami perilaku sistem yang kompleks dari waktu ke waktu. Ini berkaitan dengan umpan balik internal dan waktu tunda yang mempengaruhi perilaku keseluruhan sistem (Sterman, 2004). Apa yang membuat system dynamics berbeda dari pendekatan lain untuk mempelajari sistem yang kompleks adalah penggunaan loop umpan balik dan persediaan dan aliran. Unsur-unsur ini membantu menjelaskan cara sistem yang tampaknya sederhana menampilkan model nonlinier yang membingungkan (Howe dan Lewis, 2005). Ada dua jenis skema 
diagram utama yang digunakan dalam system dynamics untuk menyampaikan hubungan antara variabel. Pertama adalah Causal Loop Diagram (CLD) dan kedua adalah Stock and Flow Diagram (SFD). Langkah untuk membangun model system dynamics (Chang, et al., 2008), yaitu menyusun konsep dalam sebuah model CLD (Causal Loop Diagram), membuat model diagram alir atau SFD (Stock and Flow Diagram), melakukan simulasi berupa diagram waktu dan tabel waktu dan memvalidasi hasil simulasi.

Proyek Remote Solution menghasilkan keluaran site BTS Ramah Lingkungan yang menghadirkan jasa telekomunikasi di daerah rural. Ini merupakan suatu dinamika sistem yang kompleks (berubah terhadap waktu), sehingga pengkajian permasalahan dalam penelitian ini dilakukan melalui pengkajian sistem. Pada penelitian ini variabel konsumsi penggunaan voice call dan sms akan mempengaruhi pencapaian revenue dan ARPU digambarkan dalam satu model yang saling berhubungan (Gambar 1) Keempat variabel tersebut disimulasikan secara system dynamics dengan bantuan software Powersim (Avianto, 2006) melalui model terbangun yang digambarkan dalam bentuk Stock Flow Diagram (Gambar 2). Melalui pemodelan dapat diperoleh gambaran kondisi riil di lokasi site BTS Ramah Lingkungan, yaitu ARPU yang diperoleh berada dibawah target yang ditetapkan. Sedangkan melalui simulasi dapat dicari model yang paling cocok sebelum diterapkan dalam kondisi sebenarnya sebagai tindakan koreksi terhadap revenue gap serta dapat meramalkan kondisi yang akan terjadi di masa depan.

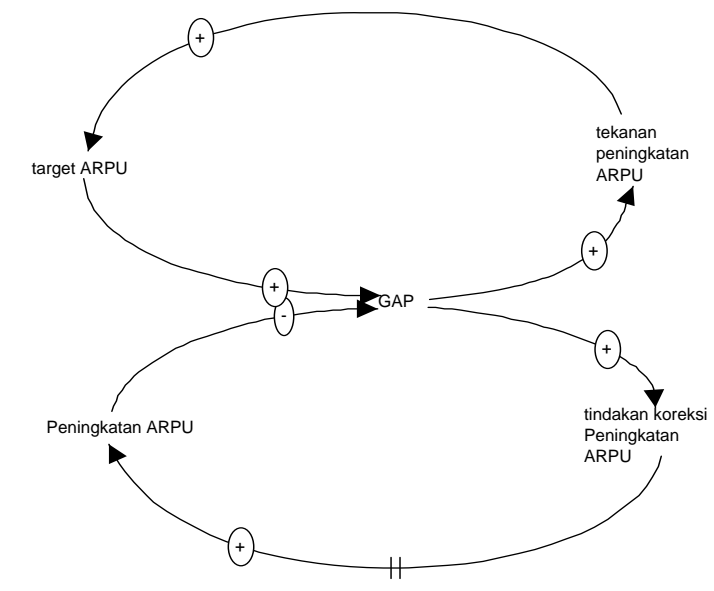

Gambar 1 Causal loop diagram kerangka konsep peningkatan ARPU model system dynamics pada site BTS Ramah Lingkungan

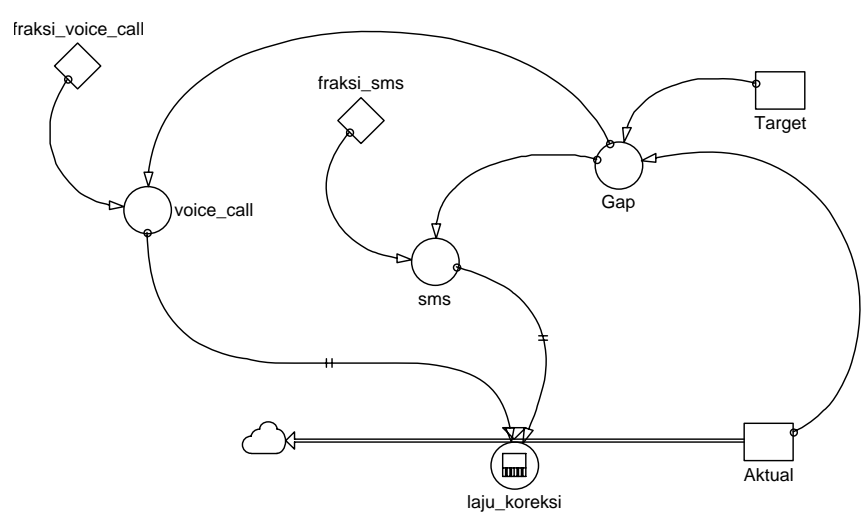

Gambar 2 Stock flow diagram kerangka konsep peningkatan ARPU model system dynamics pada site BTS Ramah Lingkungan 


\section{METODE}

Metode analisis data yang digunakan adalah system dynamics. Analisis terhadap data dilakukan untuk melihat hubungan sebab akibat dan umpan balik antar elemen (variabel) sehingga dapat ditentukan pengaruh dari setiap elemen dalam suatu sistem. Urut-urutan untuk membangun model system dynamics yaitu menyusun konsep dalam sebuah model CLD (Causal Loop Diagram), membuat model diagram alir atau SFD (Stock and Flow Diagram), melakukan simulasi berupa diagram waktu dan tabel waktu dan memvalidasi hasil simulasi. (Gambar 3).

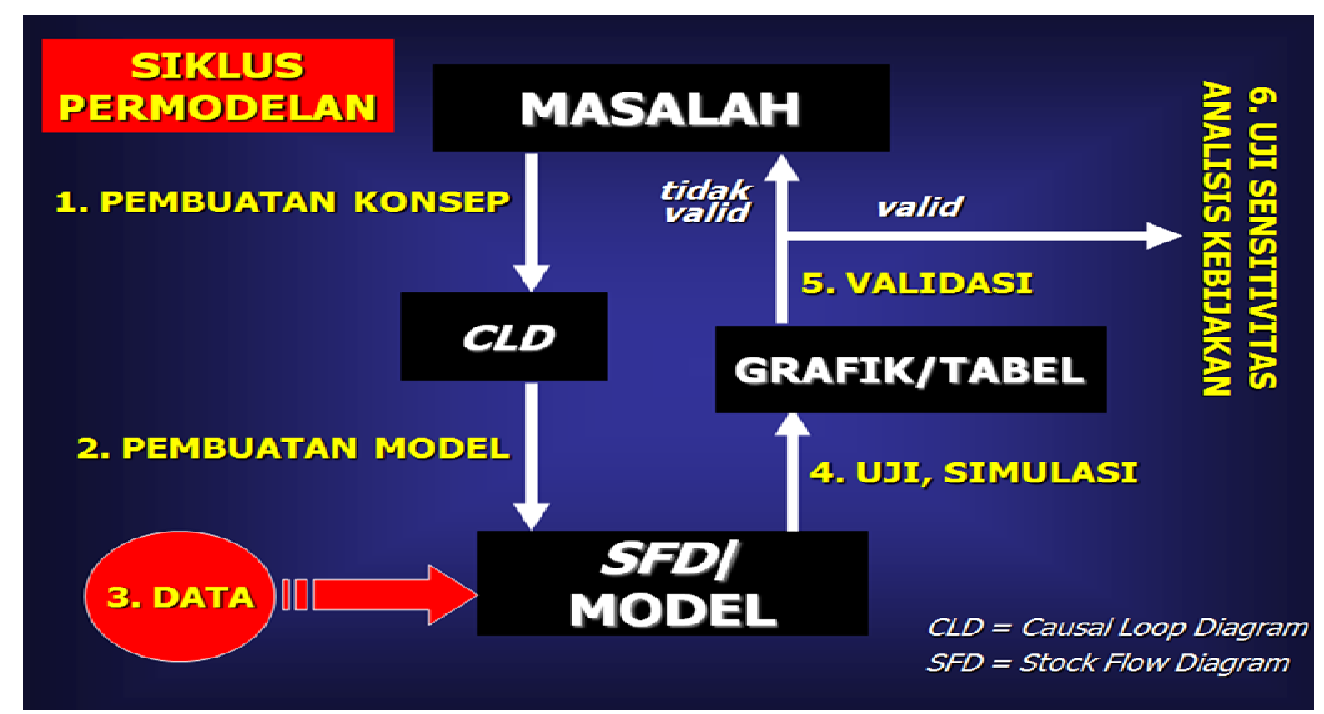

Gambar 3 Siklus permodelan System dynamics

\section{HASIL PEMBAHASAN}

\section{Kondisi Awal Infrastruktur BTS Ramah Lingkungan}

Simulasi model kenaikan target revenue per bulan didasarkan pada data tahun 2011 yang meliputi data jumlah pelanggan rata-rata dan jumlah revenue aktual per BTS (Tabel 1 dan Gambar 4). Nilai aktual ARPU per bulan adalah Rp. 25.400,00, sementara target ARPU per bulan Rp. 30.000,00. Rata-rata pemakaian layanan voice call dan SMS per pelanggan selama 1 bulan adalah 7 menit dan 104 SMS. Adapun tarif voice call yang berlaku di site BTS Ramah Lingkungan sebesar Rp. 1.400,00/menit dan tarif pesan singkat Rp. 150,00/SMS.

Tabel 1 Komposisi Jumlah Pelanggan Rata-Rata, Laju Pertumbuhan Pelanggan dan Revenue pada BTS Ramah Lingkungan

\begin{tabular}{cccccc}
\hline No & Bulan & $\begin{array}{c}\text { Rata-rata } \\
\text { pelanggan } \\
\text { aktual per } \\
\text { BTS }\end{array}$ & $\begin{array}{c}\text { Laju } \\
\text { Pertumbuhan } \\
\text { Pelanggan }\end{array}$ & Aktual Revenue & Target Revenue \\
\hline 1 & Januari-2011 & 460 & 0 & Rp. 11.971.300,00 & Rp. 13.785.000,00 \\
\hline 2 & Februari-2011 & 476 & 0,037 & Rp. 13.016.933,00 & Rp. 15.020.000,00 \\
\hline 3 & Maret-2011 & 526 & 0,105 & Rp. 13.935.567,00 & Rp. 16.105.000,00 \\
\hline
\end{tabular}




\begin{tabular}{clcccc}
\hline No & Bulan & $\begin{array}{c}\text { Rata-rata } \\
\text { pelanggan } \\
\text { aktual per } \\
\text { BTS }\end{array}$ & $\begin{array}{c}\text { Laju } \\
\text { Pertumbuhan } \\
\text { Pelanggan }\end{array}$ & Aktual Revenue & Target Revenue \\
\hline 4 & April-2011 & 539 & 0,024 & Rp. 14.913.467,00 & Rp. $17.260 .000,00$ \\
\hline 5 & Mei-2011 & 566 & 0,050 & Rp. 16.043.767,00 & Rp. 18.595.000,00 \\
\hline 6 & Juni-2011 & 683 & 0,207 & Rp. 17.601.633,00 & Rp. 20.435.000,00 \\
\hline 7 & Juli-2011 & 702 & 0,028 & Rp. 18.596.467,00 & Rp. 21.610.000,00 \\
\hline 8 & Agustus-2011 & 704 & 0,004 & Rp. 19.608.233,00 & Rp. 22.805.000,00 \\
\hline 9 & September-2011 & 732 & 0,040 & Rp. 20.539.000,00 & Rp. 23.550.000,00 \\
\hline 10 & Oktober-2011 & 751 & 0,026 & Rp. 20.967.133,00 & Rp. 24.410.000,00 \\
\hline 11 & Nopember-2011 & 780 & 0,038 & Rp. 21.597.900,00 & Rp. 25.155.000,00 \\
\hline 12 & Desember-2011 & 834 & 0,070 & Rp. 22.939.867,00 & Rp. 26.740.000,00 \\
\hline
\end{tabular}

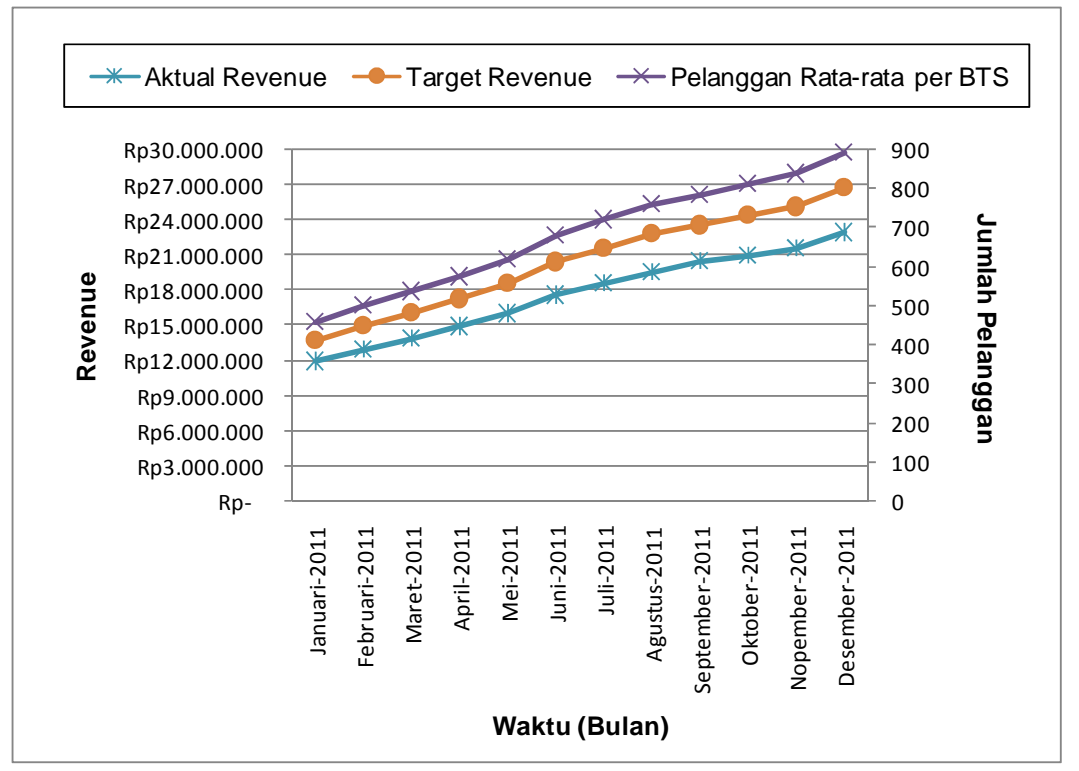

Gambar 4 Grafik kondisi awal jumlah pelanggan dan revenue (Hasil pengolahan data peneliti, 2012)

Berdasarkan Tabel 1, terlihat bahwa di setiap bulan terdapat gap pada site remote, yaitu selisih antara nilai aktual revenue dan target revenue yang memberikan nilai negatif.

\section{Pola pada BTS Site Ramah Lingkungan di Masa Depan}

Tren pelanggan dan revenue pada site BTS Ramah Lingkungan untuk periode lima tahun (2012-2016) memberikan kecenderungan meningkat (Gambar 5). Adapun pola data dibuat dengan menggunakan asumsi bahwa laju pertumbuhan pelanggan per bulan adalah konstan yaitu 0,07 dan ARPU per bulan Rp.30.000,00.

\section{Menghilangkan Gap melalui Tindakan Koreksi terhadap Revenue}

Tindakan koreksi terhadap revenue untuk menghilangkan gap sekaligus memenuhi target revenue per bulannya dapat dilakukan dengan cara: (1) meningkatkan marketing campaign (kampanye pemasaran); (2) melakukan koreksi terhadap ARPU (tarif); (3) memberlakukan promo bonus pemakaian layanan kepada pelanggan. 
Pada Gambar 6 ditunjukkan hubungan antara gap dan laju koreksi terhadap revenue (pengaruh dari tindakan koreksi). Gambar kurva menunjukkan kondisi di mana gap dan laju koreksi terhadap revenue secara perlahan meningkat dari yang bernilai negatif (minus) hingga mencapai nilai positif (di atas 0 ).

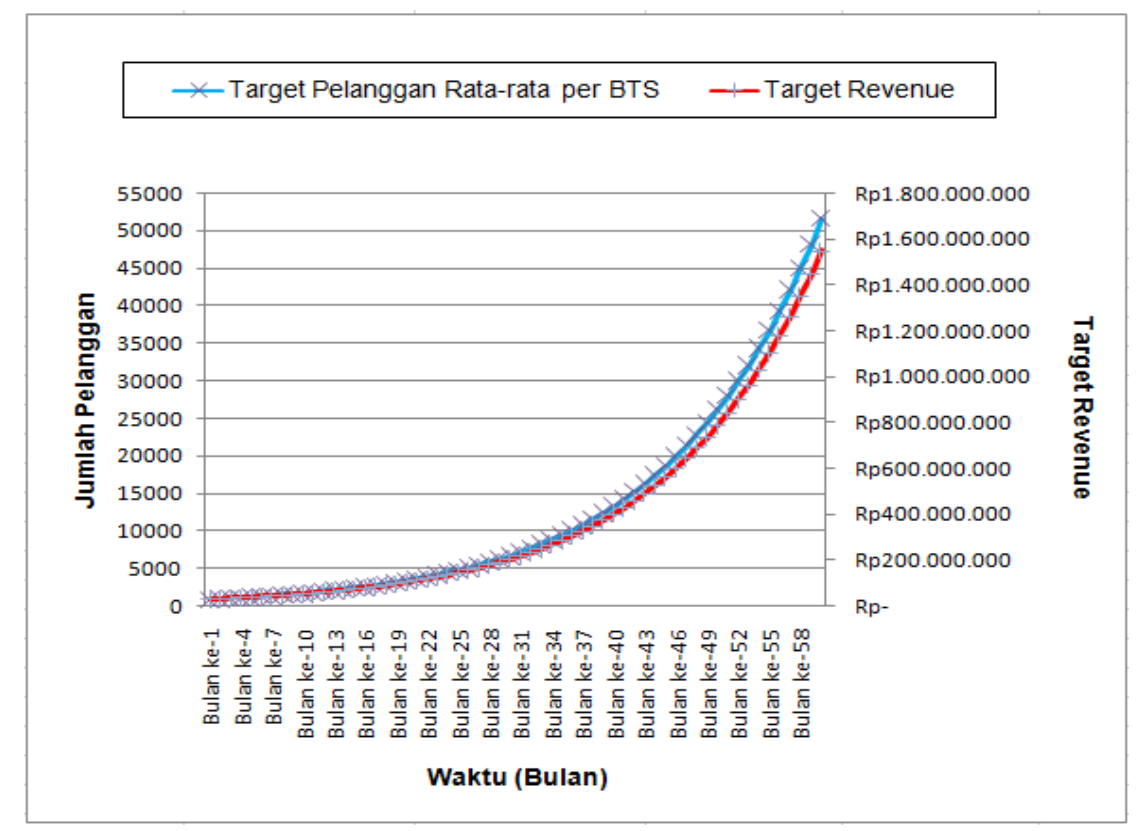

Gambar 5 Grafik target pelanggan dan revenue periode 5 tahun (2012-2016)

(Hasil pengolahan data peneliti, 2012)

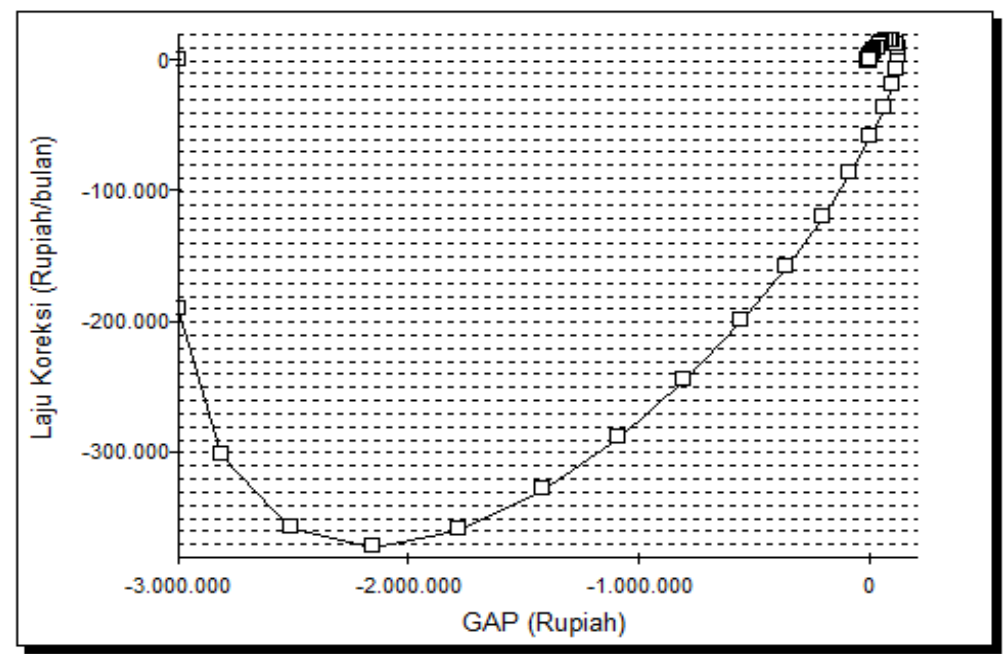

Gambar 6 Grafik hubungan gap terhadap laju koreksi revenue (Hasil output simulasi dengan Powersim 2.5, 2012)

Sementara Gambar 7 menunjukkan peningkatan aktual revenue sebagai akibat dilaksanakannya tindakan koreksi terhadap revenue. 


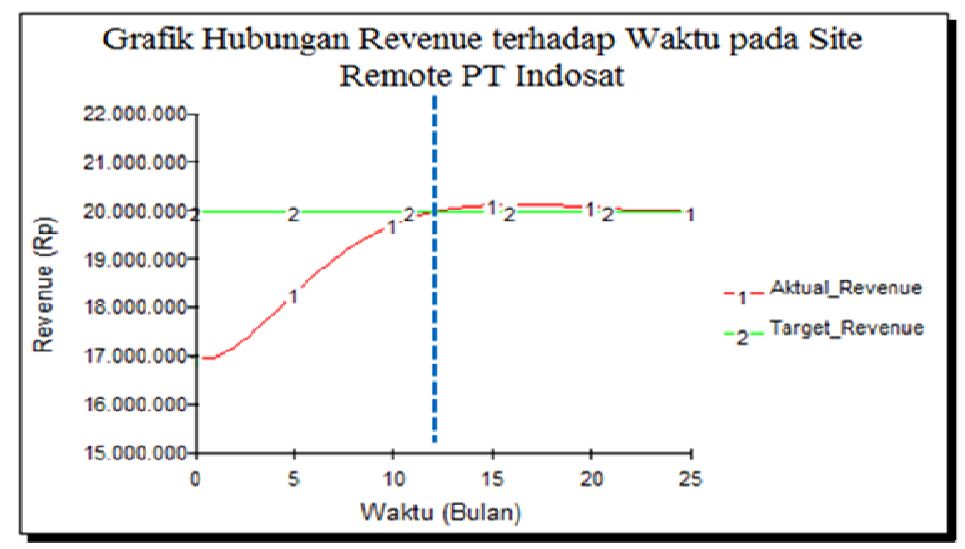

Gambar 7 Grafik hubungan pencapaian revenue terhadap waktu di site remote

(Sumber: Hasil output simulasi dengan Powersim 2.5, 2012)

\section{Menghilangkan Gap melalui Strategi Intervensi}

Terdapat kondisi yang harus dipenuhi pada simulasi baru dengan strategi intervensi guna menghilangkan gap di site remote (Gambar 8). Kondisi 1: Gap (aktual revenue - target revenue) harus sudah bernilai positif pada bulan ke-15 dari simulasi awal sebelum dilakukan intervensi. Jika kondisi 1 terpenuhi, maka tidak perlu lagi memperhatikan kondisi 2. Kondisi 2: Apabila kondisi 1 tidak terpenuhi, tindakan koreksi terhadap revenue harus memperhatikan variabel jumlah pelanggan aktual. Pada bulan ke-15, jumlah pelanggan aktual harus mencapai minimal 1.000 orang pelanggan. Jika tidak terpenuhi, maka dilakukan tindakan relokasi BTS. Relokasi BTS yaitu memindahkan BTS Ramah Lingkungan ke lokasi lain yang lebih potensial dengan tujuan agar gap antara aktual dan target revenue menunjukkan nilai yang positif sejak bulan pertama BTS tersebut dioperasikan.

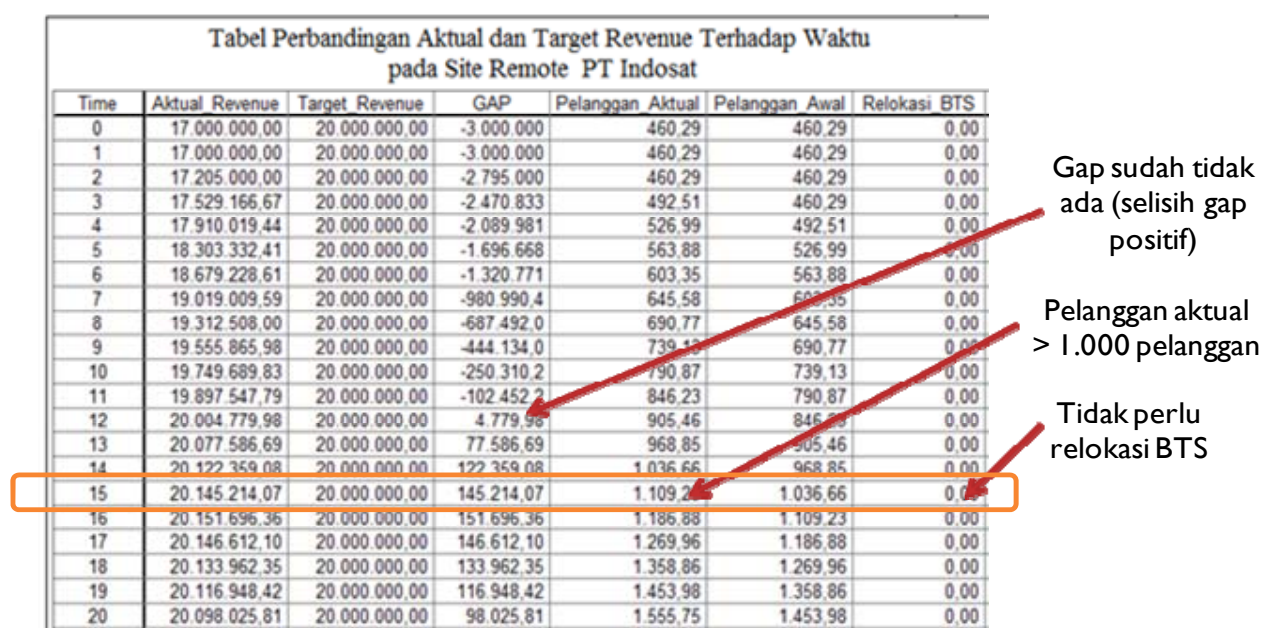

Gambar 8 Hasil Simulasi System Dynamics menggunakan Powersim v.2.5

(Hasil output simulasi dengan Powersim 2.5, 2012)

\section{Uji Validitas Hasil Simulasi}

Setelah permodelan selesai dilakukan dan ada hasilnya, perlu dilakukan uji validitas dalam rangka pengujian keberlakuan data nyata terhadap simulasi untuk data jumlah pelanggan rata-rata per BTS dan aktual revenue (Tabel 2 dan 3). 
Tabel 2 Validasi Pelanggan Rata-Rata Per BTS untuk Data Riil dan Hasil Simulasi

\begin{tabular}{lccr}
\hline \multicolumn{1}{c}{ Bulan } & $\begin{array}{c}\text { Pelanggan Rata- } \\
\text { rata per BTS }\end{array}$ & $\begin{array}{c}\text { Pelanggan Rata-rata } \\
\text { per BTS Hasil Simulasi }\end{array}$ & $\begin{array}{c}\text { Bias Pelanggan } \\
\text { per BTS }\end{array}$ \\
\hline Januari-2011 & 460 & 460 & $0,11 \%$ \\
\hline Februari-2011 & 501 & 460 & $-8,12 \%$ \\
\hline Maret-2011 & 537 & 493 & $-8,17 \%$ \\
\hline April-2011 & 575 & 527 & $-8,40 \%$ \\
\hline Mei-2011 & 620 & 564 & $-9,01 \%$ \\
\hline Juni-2011 & 681 & 603 & $-11,48 \%$ \\
\hline Juli-2011 & 720 & 646 & $-10,32 \%$ \\
\hline Agustus-2011 & 760 & 691 & $-9,10 \%$ \\
\hline September-2011 & 785 & 739 & $-5,86 \%$ \\
\hline Oktober-2011 & 814 & 791 & $-2,79 \%$ \\
\hline Nopember-2011 & 839 & 846 & $0,89 \%$ \\
\hline Desember-2011 & 891 & 905 & $1,53 \%$ \\
\hline
\end{tabular}

(Hasil output simulasi dengan Powersim 2.5, 2012)

Tabel 3 Validasi Aktual Revenue pada Data Riil dan Hasil Simulasi

\begin{tabular}{lccr}
\hline \multicolumn{1}{c}{ Bulan } & Aktual Revenue & $\begin{array}{c}\text { Aktual Revenue } \\
\text { Hasil Simulasi }\end{array}$ & Bias Aktual Revenue \\
\hline Januari-2011 & Rp. 11.971.300,00 & Rp. 17.000.000,00 & $42,01 \%$ \\
\hline Februari-2011 & Rp. 13.016.933,00 & Rp. 17.205.000,00 & $32,17 \%$ \\
\hline Maret-2011 & Rp. 13.935.567,00 & Rp. 17.529.167,00 & $25,79 \%$ \\
\hline April-2011 & Rp. 14.913.467,00 & Rp. 17.910.019,00 & $20,09 \%$ \\
\hline Mei-2011 & Rp. 16.043.767,00 & Rp. 18.303.332,00 & $14,08 \%$ \\
\hline Juni-2011 & Rp. 17.601.633,00 & Rp. 18.679.229,00 & $6,12 \%$ \\
\hline Juli-2011 & Rp. 18.596.467,00 & Rp. 19.019.010,00 & $2,27 \%$ \\
\hline Agustus-2011 & Rp. 19.608.233,00 & Rp. 19.312.508,00 & $-1,51 \%$ \\
\hline September-2011 & Rp. 20.539.000,00 & Rp. 19.555.866,00 & $-4,79 \%$ \\
\hline Oktober-2011 & Rp. 20.967.133,00 & Rp. 19.749.690,00 & $-5,81 \%$ \\
\hline Nopember-2011 & Rp. 21.597.900,00 & Rp. 19.897.548,00 & $-7,87 \%$ \\
\hline Desember-2011 & Rp. 22.939.867,00 & Rp. 20.004.780,00 & $-12,79 \%$ \\
\hline
\end{tabular}

(Hasil output simulasi dengan Powersim 2.5, 2012)

Berdasarkan hasil perhitungan uji validitas diperoleh bias rata-rata 5,89\% untuk jumlah pelanggan rata-rata per BTS dan 9,15\% untuk aktual revenue. Angka bias tersebut masih di bawah $10 \%$, sehingga dapat dinyatakan bahwa data hasil permodelan valid dan layak untuk digunakan.

\section{PENUTUP}

Berdasarkan hasil simulasi menggunakan data, proses, dan asumsi yang berlaku dalam pemodelan system dynamics pada site BTS Ramah Lingkungan di daerah rural serta analisis hasil 
simulasi yang ada, dapat disimpulkan sebagai berikut: (1) model baku sasaran yang berubah (target has changed) dapat digunakan untuk menggambarkan hubungan sebab akibat umpan balik antara jumlah pelanggan, ketersediaan kapasitas jaringan dan ARPU pada site BTS Ramah Lingkungan. Pada model yang ada aktual revenue ditempatkan sebagai kejadian aktual, target revenue sebagai sasaran, selisih aktual dan target revenue sebagai gap, perubahan gap sebagai tekanan terhadap sasaran dan tindakan perbaikan yang dilakukan terhadap revenue sebagai tindakan koreksi; (2) biaya investasi telekomunikasi di daerah rural yang tinggi, keterbatasan jumlah pelanggan di sekitar site BTS Ramah Lingkungan dan persepsi penduduk lokal bahwa tarif dari layanan call/SMS di site BTS Ramah Lingkungan terlalu mahal menyebabkan revenue yang diperoleh dari bisnis pada site BTS Ramah Lingkungan berada dibawah target yang ditentukan; (3) berdasarkan hasil simulasi, intervensi terhadap tindakan koreksi revenue yaitu memindahkan BTS Ramah Lingkungan ke lokasi lain yang lebih potensial (relokasi BTS), dapat dilakukan pada bulan ke-15 setelah tindakan koreksi dijalankan dengan syarat gap (selisih antara aktual revenue dan target revenue) pada saat itu masih bernilai negatif serta jumlah pelanggan aktual belum mencapai 1.000 pelanggan; (4) penambahan dua lup negatif (balancing loop) pada model baku sasaran yang berubah (target has changed) dapat dipakai sebagai alternatif solusi menuju pencapaian target revenue yang telah ditetapkan. Hal itulah yang dimaksud dengan pengembangan model dan rekomendasi atas pengaturan kapasitas jaringan serta ARPU pada site BTS Ramah Lingkungan di daerah rural.

Dalam upaya mencapai target revenue di site BTS Ramah Lingkungan, diperlukan kebijakan perusahaan yang terintegrasi, meliputi: (1) penetapan nilai ARPU di site BTS Ramah Lingkungan agar memperhatikan kondisi sosial ekonomi penduduk local; (2) sosialisasi dan marketing campaign di lapangan tentang keberadaan site BTS remote Ramah Lingkungan termasuk keunggulannya dibanding alternatif solusi komunikasi lainnya yang sudah ada di sekitar lokasi site perlu dilakukan secara berkala dan tidak hanya dilakukan di sekitar lokasi site itu saja, namun sampai keluar area cakupan BTS Ramah Lingkungan; (3) pemberlakuan promo bonus yang menarik untuk layanan voice call dan SMS selama periode waktu tertentu serta mempertahankan kualitas jaringan telekomunikasi yang handal pada infrastruktur BTS ramah lingkungan.

\section{DAFTAR PUSTAKA}

Akkermans, H. \& Dellaert, N. (2005). The rediscovery of industrial dynamics: the contribution of system dynamics to supply chain management in a dynamic and fragmented world. System Dynamics Review, 21 (3), 173-86.

Avianto, T. W. 2006. Tutorial Powersim Constructor. Bandung: Program Magister Studi Pembangunan, Institut Teknologi Bandung.

Azis, I., Napitupulu, L., Patunru, A., Resosudarmo, B. (2010). Pembangunan Berkelanjutan - Peran dan kontribusi Emil Salim. Jakarta: Kepustakaan Populer Gramedia.

Chang, Y.C. Hong, F.W. Lee, M.T. (2008). A system dynamic based DSS for sustainable coral reef management in Kenting coastal zone, Taiwan. Ecological Modelling, 211, 153-168.

Falk, S. Narsalay, R. O’Brien, D. Sennik, R. (2009). Wanted: New business models for profitable rural expansion. Accenture Research Report.

Fauzi, A. (2004). Ekonomi Sumber Daya Alam dan Lingkungan. Jakarta: Gramedia Pustaka Utama.

Howe, M. L. \& Lewis, M. D. (2005). The importance of dynamic systems approaches for understanding development. Developmental Review, 25(3-4), 247-51. 
Materi kuliah Pasca Sarjana (S3) tidak diterbitkan. Program Studi PSL di IPB, Bogor.

Salim, E. (2006). Pengelolaan Lingkungan dalam Pembangunan.

Sterman, John D. 2004. Business Dynamics: System Thinking and Modeling for a Complex World. New York: McGraw-Hill.

Struzak, R. (2007). Building information infrastructure in rural areas. Telecom Asia 97, 227-233. 